Author version: Holocene, vol.24(6); 2014; 749-755

\title{
Early to Late Holocene Contrast in productivity, OMZ Intensity and Calcite Dissolution in the Eastern Arabian Sea
}

\author{
Sushant S. Naik ${ }^{* 1}$, Shital P. Godad ${ }^{2}$, P. Divakar Naidu ${ }^{3}$, Manish Tiwari ${ }^{4}$, A. L. Paropkari ${ }^{5}$ \\ 1,2,3,5 CSIR-National Institute of Oceanography, Goa, INDIA \\ ${ }^{4}$ National Centre for Antarctic and Ocean Research, Goa, INDIA \\ Corresponding author: Sushant S. Naik \\ email:sushant@nio.org \\ Tel:+91 8322450657 \\ Fax: +918322450602
}

\begin{abstract}
The Oxygen Minimum Zone $(\mathrm{OMZ})$ is a potential source of $\mathrm{CO}_{2}$ to the atmosphere and the extensive OMZ spread to $1.37 \times 10^{6} \mathrm{~km}^{2}$ in the northern Arabian Sea would be an important contributor to the $\mathrm{CO}_{2}$ budget. In this perspective, we report here that the eastern Arabian Sea experienced coeval increase in productivity and denitrification from $\sim 7$ to $0 \mathrm{kyr}$, which coincides with minimum dissolved oxygen levels in bottom-waters. In addition, during the same period, an increased calcium carbonate dissolution occurred as evidenced by low $\mathrm{CaCO}_{3}$ content, decreasing shell weights of planktonic foraminifer species Globigerinoides ruber with well-marked dissolution features on their shells. Therefore, this study has implications on the role of OMZ in governing $\mathrm{CaCO}_{3}$ dissolution and contributing to an increase in atmospheric $\mathrm{CO}_{2}$.
\end{abstract}

Keywords: Productivity, denitrification, OMZ, calcite dissolution, Arabian Sea 


\section{Introduction}

The Arabian Sea is unique in terms of seasonal reversals of winds during the south-west (SW) and north-east (NE) monsoon due to seasonal variations in heating of the southern Asian continent. Associated with the seasonal reversal of winds is the reversal of surface-water circulation. Strong winds blowing from the SW generate upwelling of nutrient-rich waters in the Western Arabian Sea (WAS), off Somalia/Oman leading to very high primary production, and weak and sporadic upwelling along the coasts off India and Pakistan (Eastern Arabian Sea (EAS)) (Fig. 1).The EAS receives more precipitation compared to the WAS during the SW monsoon. Most of the SW monsoon precipitation on the Western Ghats drains into the Arabian Sea through numerous rivers and streams. During the NE monsoon winds from the NE evaporate and cool the surface waters which deepens the mixed-layer and leads to input of nutrients to the surface in the Northern basin and also increases the primary productivity (Madhupratap et al., 1996). The organic production in the Arabian Sea is however significantly higher during the SW monsoon in comparison to the NE monsoon and decreases in the intermonsoonal seasons.

The Arabian Sea is amongst the highest seasonal productivity zones in the world (Qasim, 1977). The high biological productivity prevailing during the south-west monsoon is a source of large amounts of organic matter which subsequently sinks to deeper depths (Nair et al., 1989). At intermediate depths, the oxidation of organic matter consumes dissolved oxygen and therefore the entire Arabian Sea is characterized by a permanent, intense Oxygen Minimum Zone (OMZ) between depths of 150-1200m (Wyrtki, 1971; Von Stackelberg, 1972). In the OMZ, bacterial degradation of organic matter takes place, which reduces $\mathrm{NO}_{3}{ }^{-}$and produces $\mathrm{N}_{2}$ and $\mathrm{N}_{2} \mathrm{O}$ in the water-column by a chain of processes known as denitrification (Deuser et al., 1978; Naqvi, 1991). OMZs are important due to their climatic interactions and impacts on ecosystems for eg., their contribution to major greenhouse gases such as $\mathrm{CO}_{2}$ and $\mathrm{N}_{2} \mathrm{O}$ (Resplandy et al., 2012). Modern observations suggest that the volume of OMZs' suboxic waters has increased over the past decades (Stramma et al., 2008) and could further expand due to ocean warming and climate change (Sarmiento et al., 1998; Keeling et al., 2010). Therefore, improving our understanding of OMZs is of primary importance when considering the future evolution and impacts of OMZs (Resplandy et al., 2012). Several studies were carried out to understand variations in productivity/denitrification and OMZ intensity in the EAS focussed on glacial-interglacial or longer timescales (Schulz et al., 1998; Reichart et al., 1998; Schulte et al., 1999; von Rad et al., 1999b; Ganeshram et al., 2000; Agnihotri et al., 2002; Reichart et al., 2004; Pichevin et al., 2007; Böning and Bard, 2009) and few studies covering shorter 
timescales in the EAS (Von Rad et al., 1999a; Agnihotri et al., 2003; Agnihotri et al., 2008). The $\mathrm{OMZ}$ is known to be intense during the Holocene, in particular during the Late Holocene (Gupta et al., 2011) controlled by the supply of oxygen depleted intermediate waters combined with elevated monsoon-controlled oxygen demand (Böning and Bard, 2009).

Our understanding on the dissolution/preservation of calcite in response to varying intensity of the OMZ is very little. In the present study we have examined a sediment core from the EAS with high sedimentation, covering the Holocene period, in order to address the changes in productivity, denitrification, oxygenation of bottom waters and to understand the influence of OMZ on the dissolution/preservation of calcite.

\section{Materials and Methods}

Core AAS9/19 (14 $30.115^{\prime} \mathrm{N} ; 7^{\circ} 08.515^{\prime} \mathrm{E}$; water depth of $367 \mathrm{~m}$; Fig. 1.) was recovered from the OMZ region, much above the present day lysocline $(\sim 3800 \mathrm{~m}$; Peterson and Prell, 1985$)$ as well as the present day Aragonite Compensation Depth (ACD) (von Rad et al., 1999b). The chronology of this core was based on four AMS ${ }^{14} \mathrm{C}$ dates and covers 12.3 kyrs (Table 1 ). AMS ${ }^{14} \mathrm{C}$ dating was performed on monospecific samples of the planktic foraminiferal species G. ruber using the Tandem Accelerator at Leibniz Laborfür Altersbestimmung und Isotopenforschung, ChristianAlbrechts-Universität, Kiel, Germany. Measured ${ }^{14} \mathrm{C}$ ages were converted to sediment ages using the online CALIB radiocarbon calibration programme version 7.0 (Stuiver et al., 2005). Before calibration, radiocarbon dates were corrected for a reservoir effect ( $\Delta \mathrm{R}=125 \pm 37$ years) based on observations for the Indian Ocean (Dutta et al., 2001).

All the samples were oven dried at $50^{\circ} \mathrm{C}$; a portion of the sample was weighed and disaggregated by soaking in distilled water and then wet sieved through a $>63 \mu \mathrm{m}$ sieve. For shell weight measurements, the coarse material was further sieved in the size range of 300-355 $\mu \mathrm{m}$. Approximately thirty G. ruber (white) shells were picked from this size fraction under a Stereo-zoom binocular microscope and weighed on a microbalance ( $1 \sigma$ precision: $\pm 1.5 \mu \mathrm{g}, \mathrm{n}=10$ ).

Isotopic analysis on G. ruber specimens from a size range of 250-350 $\mu \mathrm{m}$ were done using a Finnigan MAT 252 mass spectrometer equipped with an automatic carbonate preparation device at the Universität Bremen, Germany. The mean external error and reproducibility(1s) of carbonate standard is better than $\pm 0.07 \%$ and $\pm 0.05 \%$ for $\delta^{18} \mathrm{O}$ and $\delta^{13} \mathrm{C}$, respectively. Oxygen and carbon isotopic values are expressed as per mil (\%) deviation Vienna Pee Dee belemnite (VPDB) standard, calibrated by NBS 18, 19 and 20 standards. 
The carbon and nitrogen concentrations and their isotope values were measured the Marine Stable Isotope Lab (MASTIL) at the National Centre for Antarctic \& Ocean Research, Goa, India using an Isoprime Stable Isotope Ratio Mass Spectrometer in continuous-flow mode coupled with an EA (Isoprime, Vario Isotope Cube). The external precisions on $\delta^{13} \mathrm{C} \& \delta^{15} \mathrm{~N}$ are $\pm 0.04 \%$ \% $\pm 0.07 \%$ o ( $1 \sigma$ standard deviation) respectively obtained by repeatedly running Cellulose (IAEA-CH-3) \& Ammonium sulphate(IAEA-N1) standards $(\mathrm{n}=21)$. The external precisions for $\mathrm{C} \%$ \& $\mathrm{N} \%$ are $\pm 0.39 \%$ \& $\pm 0.46 \%$ respectively ( $1 \sigma$ standard deviation) obtained by repeatedly running Sulfanilamide as the standard $(n=21) . \delta^{13} \mathrm{C}$ values are reported with respect to $\mathrm{V}-\mathrm{PDB}$ and $\delta^{15} \mathrm{~N}$ values are reported with respect to air $\mathrm{N}_{2}$. The reference standard used for normalizing to V-PDB and air $\mathrm{N}_{2}$ scale are Cellulose (IAEA-CH-3) \& Ammonium sulphate (IAEA-N1).

For elemental analysis, about $50 \mathrm{mg}$ of sediment was weighed in a Teflon beaker. To this 10 $\mathrm{ml}$ of acid mixture of $\mathrm{HF}+\mathrm{HNO}_{3}+\mathrm{HClO}_{4}(7: 3: 1$ ratio) was added and the contents were concentrated to a paste by placing the beaker on a hot plate. To this paste $4 \mathrm{ml}$ of $1: 1 \mathrm{HNO}_{3}$ was added. After heating for $5 \mathrm{~min}$ the material was diluted with ultrapure $(18.2 \mathrm{M} \Omega$ ) water to a final volume of 100 $\mathrm{ml}$. Similar digestion procedure was followed for standard reference materials (MAG-1, SGR-1) and blanks. These solutions were analyzed for $\mathrm{Ti}, \mathrm{Cr}$ and $\mathrm{Mo}$ on an inductively coupled plasma-mass spectrometer (Thermo X Series 2) at NIO, Goa. The accuracy compared to the standard reference material and the precision of the data based on duplicate analysis was better than $\pm 6 \%$. The calcium carbonate content was determined with a coulometer (UIC, Inc-CM5130 acidification module). Analytical grade calcium carbonate was used as the standard reference material. The accuracy and precision of measurements based on analysis of duplicate samples and standard reference material were within $\pm 2 \%$.

\section{Results}

The $\mathrm{CaCO}_{3}$ content varied from 38 to $72 \%$ with higher values encountered during early Holocene (from $\sim 12$ to $7 \mathrm{kyr}$ ) (Fig. 2a). The Organic Carbon (OC) content varied from 0.8 to $5 \%$ with low OC values during the early Holocene and a gradual increase beginning from $\sim 7 \mathrm{kyr}$ (Fig. $2 \mathrm{~b}$ ). The core top values are within the range of OC values obtained from the continental margin sediments (Paropkari et al.,1992). N content varied from 0.1 to $0.7 \%$ with variations similar to that of $\mathrm{OC}\left(\mathrm{r}^{2}=0.87, \mathrm{n}=36\right)$ (Fig. $2 \mathrm{~d}$ ). $\mathrm{C} / \mathrm{N}$ values range from 3.7 to 14.5 units (Fig. 2e), which are generally within those reported for marine sedimentary organic matter $8 \pm 2$ (Reichart et al., 1997; Bhushan et al., 2001). Higher values during the early Holocene could be due to contribution from terrestrial organic matter. $\delta^{13} \mathrm{C}_{\text {org }}$ values range from -21 to $-22 \%$ (Fig. $2 \mathrm{f}$ ). A crossplot of $\delta^{13} \mathrm{C}_{\text {org }}$ 
versus $\mathrm{C} / \mathrm{N}$ ratios shows all values in the range of marine organic matter (Meyers, 1994) (Fig.3) indicating that deposition of organic matter at this site has been predominantly of marine origin throughout the Holocene. $\delta^{15} \mathrm{~N}$ values range from 3.4 to $7 \%$ with lower values during the early Holocene and gradually increasing towards the Late Holocene (Fig. 2c). The $\delta^{15} \mathrm{~N}$ values of the top sections of the present core are in the range observed for the EAS (Agnihotriet al., 2003). The $\delta^{13} \mathrm{C}$ of G. ruber varied from 0.86 to $1.59 \%$ o (Fig. 2g). Molybdenum concentrations varied from 1.3 to 9.7 ppm and Chromium concentrations varied from 137 to 214 ppm. Higher concentrations of Mo and Cr were noted during 7-0 kyr. Ti showed a decreasing trend through the Holocene period with concentrations varying from 0.3 to $0.8 \mathrm{wt} \%$ (Fig. $2 \mathrm{~h}$ ) and are positively correlated to $\mathrm{CaCO}_{3}\left(\mathrm{r}^{2}=\right.$ $0.36, \mathrm{n}=36$ ) suggesting that terrigenous dilution is not the cause for $\mathrm{CaCO}_{3}$ variations. The shell weights of Globigerinoides ruber range from 13 to $19 \mu \mathrm{g}$ (Fig $2 \mathrm{~m}$ ). Higher shell weights were noticed during Younger Dryas (YD) and early Holocene and then a decrease in shell weights was noticed throughout the Holocene period. On an average the $\sim 12-7 \mathrm{kyr}$ shells weighed $\sim 17 \mu \mathrm{g}$ and the 7-0 kyr shells weighed $\sim 14 \mu \mathrm{g}, \mathrm{a} \sim 3 \mu \mathrm{g}$ decrease in shell weights during the Late Holocene. Scanning Electron Micrographs (SEM) were taken on a 6360 LV, JEOL instrument.

\section{Discussion}

\section{Changes in surface productivity, denitrification and bottom-water oxygenation intensity}

Organic matter $(\mathrm{OM})$ input is either generated by primary production in the photic zone or through transport of terrestrial $\mathrm{OM}$ to the marine realm. The organic carbon (OC) content of sediments depends upon various factors such as sedimentation rates, oxygen exposure times and organic matter composition (amount of refractory and non-refractory components) (see Zonneveld et al., 2010). Studies on the OC distribution in surficial sediments collected along the western continental margin of India suggest that primary productivity is the major controlling factor (Calvert et al., 1995). The AAS9/19 sediment core is located on the continental slope, characterised by the presence of fine material, high sedimentation rates, presence of OMZ and therefore high organic carbon content. The OC content shows higher values during the Late Holocene and appears to reflect surface water productivity variations.

The $\delta^{13} \mathrm{C}$ of planktonic foraminifera can vary in response to productivity changes, carbonate chemistry of seawater and upwelling processes (Peeters et al., 2002). In the EAS, the processes of upwelling and winter convective mixing aid in bringing ${ }^{13} \mathrm{C}$ depleted subsurface waters to the surface, eventually depleting $\delta^{13} \mathrm{C}$ of the surface waters. Planktonic foraminifera calcifying in these 
waters record lower $\delta^{13} \mathrm{C}$ in their shells. On the other hand an increase in surface productivity increases the $\delta^{13} \mathrm{C}$ of surface seawater. Increasing productivity is also linked to upwelling of nutrientrich subsurface waters, foraminifera taking in ${ }^{12} \mathrm{C}$ preferentially over ${ }^{13} \mathrm{C}$ and hence the organic matter gets enriched in ${ }^{12} \mathrm{C}$. Therefore the $\delta^{13} \mathrm{C}$ in shells is a net result of whichever process dominates. We observe lower values of $\delta^{13} \mathrm{C}_{G \text {.ruber }}$ and $\delta^{13} \mathrm{C}_{\text {org }}$ beginning from $\sim 7 \mathrm{kyr}$ and a positive relationship between the two parameters which also advocates the increase in productivity during this period. In summary, the Late Holocene period from $\sim 7$ to $0 \mathrm{kyr}$ is dominated by higher productivity as seen from the high $\mathrm{OC} \%$, low $\delta^{13} \mathrm{C}_{\mathrm{org}}$ and low $\delta^{13} \mathrm{C}$ of planktic foraminifera as a result of increase in intensity of upwelling/winter convective mixing.

Productivity increase is linked to an increase in denitrification. Arabian Sea is one of the most important regions wherein water-column denitrification occurs. Denitrification results in enrichment of ${ }^{15} \mathrm{~N}$ in residual $\mathrm{NO}_{3}{ }^{-}$and the lighter isotope $\left({ }^{14} \mathrm{~N}\right)$ is consumed relatively faster due to kinetics. The heavier $\mathrm{NO}_{3}{ }^{-}$is then supplied to the ocean surface via upwelling and gets incorporated in newly formed particulate organic matter. Thus, the nitrogen isotopic composition $\left(\delta^{15} \mathrm{~N}\right)$ of particulate organic matter depositing in sediments has been used as a proxy for the intensity of water-column denitrification in the past (Altabet et al., 1995; 1999; Ganeshram et al., 1995). However, certain processes affect this proxy such as mixing with isotopically lighter terrestrial organic matter, organic matter alteration in water column and sediments, incomplete nitrate utilisation, variability in nitrogen fixation, etc. (See Ganeshram et al., 2000). We observed that organic matter deposited at this site is of marine origin and therefore temporal variations in $\delta^{15} \mathrm{~N}$ are not a result of mixing or dilution due to terrestrial organic matter. Furthermore, lack of correlation between $\delta^{13} \mathrm{C}_{\text {org }}$ and $\delta^{15} \mathrm{~N}$ suggests that spatial variations in $\delta^{15} \mathrm{~N}$ are not due to mixing of terrestrial and marine organic matter (Peters et al., 1978). Significant positive relationships between $\delta^{15} \mathrm{~N}-\mathrm{OC}$ and $\delta^{15} \mathrm{~N}-\mathrm{N}\left(\mathrm{r}^{2}=0.86, \mathrm{n}=36\right)$ rule out any early diagenetic effect of organic matter degradation on the $\delta^{15} \mathrm{~N}$ signal (Agnihotri et al., 2003). Incomplete nitrate utilisation, i.e. preferential uptake of $14 \mathrm{~N}_{\mathrm{NO} 3-}$ by phytoplankton leading to increase in ${ }^{15} \mathrm{~N}$ in the remaining nitrate pool, and lowering of ${ }^{15} \mathrm{~N}$ in the sinking OM, is a process which is not of importance in the eastern Arabian Sea, due to near-complete utilization of available nutrients (Altabet et al., 1999). Enhancement of nitrogen fixation by cyanobacteria can produce isotopically lighter $\delta^{15} \mathrm{~N}$ as they mostly use atmospheric nitrogen with very little fractionation (See Ganeshram et al., 2000). However, in the eastern Arabian Sea, nitrogen fixation does not have much effect on ${ }^{15} \mathrm{~N}_{\mathrm{NO} 3-}$ (Altabet et al., 1999). $\delta^{15} \mathrm{~N}$ values in AAS9/19 are significantly correlated with OC content $\left(\mathrm{r}^{2}=0.8, \mathrm{n}=36\right)$ which suggests that subsurface denitrification is controlled by the extent of 
biological productivity. Thus, we infer that present core location has experienced intense denitrification during Late Holocene from $\sim 7$ to $0 \mathrm{kyr}$.

Variations in surface productivity are expected to induce changes in oxygen level of bottom waters/sediment-water interface due to organic matter degradation. Redox conditions of bottom waters/sedimentary column strongly influence the distribution of some of the trace elements, such as Mo and $\mathrm{Cr}$ amongst others. In anoxic basins, $\mathrm{Cr}$ (VI) appears to be rapidly reduced to the $\mathrm{Cr}$ (III) state and removed from solution. Mo lacks chemical reactivity under oxic conditions but is enriched to a great extent in anoxic conditions (see Calvert et al., 1993). In modern anoxic environments, Mo shows a strong positive correlation to OC (Algeo and Lyons, 2006) as seen in the present core $\left(\mathrm{r}^{2}=\right.$ $0.48, \mathrm{n}=36$ ). Downcore variations of $\mathrm{Mo}$ and $\mathrm{Cr}$, normalized to $\mathrm{Al}$ or $\mathrm{Ti}$, are often used to infer paleo-redox conditions at the sediment-water interface at the time of deposition. $\mathrm{Ti}$ in marine sediment is mostly of continental origin and supplied through eolian and fluvial pathways. $\mathrm{Cr} / \mathrm{Ti}$ and Mo/Ti both show higher values during the Late Holocene (Fig $2 \mathrm{i}$ and $2 \mathrm{j}$ ) which suggests prevalence of sub-oxic waters during the Late Holocene. Continuous rise in denitrification and OMZ intensity through the Holocene was proposed to be due to the sluggish circulation of the Red Sea and Persian Gulf waters, which reached its present state at around $6 \mathrm{kyr}$ and this prevented the oxygen-rich southern water masses to the northern Arabian Sea enabling a continuous build-up of oxygen deficiency (Pichevin et al., 2007).

\section{Calcite dissolution due to variations in bottom-water oxygenation}

Geochemical proxies such as $\mathrm{OC}, \mathrm{N}, \mathrm{C} / \mathrm{N}, \delta^{15} \mathrm{~N}, \delta^{13} \mathrm{C}_{\mathrm{org}}$, and $\delta^{13} \mathrm{C}_{\text {G.ruber }}$ from core AAS9/19 suggest that in comparison to the early Holocene, surface productivity increased during middle to Late Holocene and so did the intensity of denitrification. Increased denitrification must have also lead to a better preservation of $\mathrm{OC}$ during the Late Holocene. Moreover, $\mathrm{Cr} / \mathrm{Ti}$ and $\mathrm{Mo} / \mathrm{Ti}$ from the same core do suggest that bottom-waters were suboxic, which means that the OMZ intensity increased during this period. Oxygenated bottom-water conditions prevailed during the early Holocene and YD wherein sediments were rich in carbonate, aragonite and pteropods and low in OC and redox sensitive elements (von Rad et al., 1999b). There is also a strong anticorrelation between $\mathrm{CaCO}_{3}$ and $\delta^{15} \mathrm{~N}\left(\mathrm{r}^{2}=0.74, \mathrm{n}=36\right)$ which suggest that during the Late Holocene $\mathrm{CaCO}_{3}$ dissolution was a result of increased OMZ intensity. This implies that denitrification and calcite preservation are intimately linked and reflect $\mathrm{OMZ}$ intensity variations. We also rule out that $\mathrm{CaCO}_{3}$ content decrease during the Late Holocene was not a result of dilution by terrigenous material, by examining the Ti variations from this core which is a proxy for terrigenous dilution. The decrease in Ti concentrations 
through the Holocene, observed in AAS9/19 is reliable as such a decreasing trend was seen in another core from the EAS, 3268G5. Higher Ti during the early Holocene was probably due to increased dust supply because of stronger winds (Agnihotri et al., 2003).

OMZs have been also termed as a Carbon Maximum Zones (CMZ) since they have high dissolved inorganic carbon (DIC) concentrations and are local sources of $\mathrm{CO}_{2}$ (Paulmier et al., 2011). They could therefore induce a positive feedback for atmospheric $\mathrm{CO}_{2}$ (Paulmier et al., 2011) and lead to dissolution of $\mathrm{CaCO}_{3}$ on the seafloor. Aragonite is a metastable polymorph of $\mathrm{CaCO}_{3}$ and more soluble in water than calcite (Morse et al., 1980). Low aragonite content and absence of pteropods during the Late Holocene from a nearby core SK 17 resulted from an increase in OMZ intensity (Fig. 1, 2k and 21; Singh et al., 2007). It is also observed in Core SK 17 that Aragonite content was high during YD (Singh et al., 2007) due to inflow of oxygenated Subantarctic Mode and Antarctic Intermediate Water (SAMW-AAIW) (Böning and Bard, 2009). However the YD event is not well demarcated in all the proxies as the response of Arabian Sea to YD event is thought to be weak (Gupta et al., 2011)

Shell weights of G. ruber from AAS9/19 were heavier during the early Holocene and highest during the YD probably due to the inflow of SAMW-AAIW. Lower shell weights during the Late Holocene could be a result of dissolution or due to increasing atmospheric $\mathrm{CO}_{2}$ concentrations during the Holocene thus reducing the surface-water carbonate ion $\left(\mathrm{CO}_{3}{ }^{5}\right)$ concentrations and hence leads to thinner foraminiferal shells (Naik et al., 2010). In order to corroborate calcite dissolution during the Late Holocene, we acquired SEM micrographs of G. ruber shells at $3.57 \mathrm{kyr}$, representative of Late Holocene and 9.9 kyr, representative of early Holocene period (Fig. 4a and b). Marked dissolution features were seen on the $3.57 \mathrm{kyr}$ shells, thus providing evidence that shell weight variations are due to dissolution which occurred during the Late Holocene as a result of sub-oxic bottom waters. Based on measurements of gases trapped in Antarctic ice, Indermühle et al. (1999) demonstrate that the $\mathrm{CO}_{2}$ content of the atmosphere rose by $20 \mathrm{ppm}$ between $8000 \mathrm{BP}$ and the onset of the Little Ice Age. This $\mathrm{CO}_{2}$ rise is thought to be resultant form different processes such as deposition of shallow water carbonate, carbonate compensation of land uptake during the glacial termination, terrestrial carbon uptake and release during the Holocene, the response of the ocean-sediment system to marine changes during the termination, etc. (Menviel and Joos, 2012). The $\mathrm{CO}_{2}$ release from calcite dissolution in $\mathrm{OMZ}$ regions could be an important process contributing to the Holocene $\mathrm{CO}_{2}$ rise and further studies should be aimed at quantification of $\mathrm{CO}_{2}$ released from major OMZ regions of the world through the Holocene. 


\section{Conclusions}

Productivity proxies such as $\mathrm{OC}, \delta^{13} \mathrm{C}_{\mathrm{org}}$, and $\delta^{13} \mathrm{C}_{G}$. ruber in the eastern Arabian Sea Core AAS9/19 reveal that productivity was higher during the Late Holocene ( $\sim 7$ to $0 \mathrm{kyr}$ ) in comparison to early Holocene. Downcore variations in $\delta^{15} \mathrm{~N}$ of sedimentary organic matter appear to be controlled by the extent of surface productivity. Temporal variation in $\delta^{15} \mathrm{~N}$ demonstrates that the intensity of subsurface denitrification has increased from $\sim 7 \mathrm{kyr} \mathrm{BP}$, in response to increasing surface productivity during this period. Redox sensitive elements such as Molybdenum and Chromium indicate that the OMZ intensity also increased simultaneously suggesting a strong coupling between productivity and $\mathrm{OMZ}$ intensity in the eastern Arabian Sea. The increase in OMZ intensity further lead to an increase in calcite dissolution as seen in the low $\mathrm{CaCO}_{3}$ content, lower shell weights of planktonic foraminiferal species G. ruber and visible dissolution features on $G$. ruber shells, during the Late Holocene. This calcite dissolution is probably a result of an increase in $\mathrm{DIC}$ in waters of the $\mathrm{OMZ}$ releasing $\mathrm{CO}_{2}$ to the atmosphere most likely contributing to the Holocene $\mathrm{CO}_{2}$ rise.

\section{Acknowledgements}

We thank the editor and both the reviewers for offering constructive comments which improved the interpretations in this paper. We thank Dr. S WA Naqvi, Director, NIO, for his encouragement and support. Thanks to Siddesh Nagoji, NCAOR for the analysis on IRMS and G. Parthiban, NIO for the ICP-MS analysis. SEM images were taken by Areef Sardar, NIO. Thanks are also due to Pawan Govil, BSIP for carbon isotopic analysis. MT thanks the Director NCAOR for encouragement \& Ministry of Earth Sciences for support. This is NIO contribution number:

\section{References}

Agnihotri R, Bhattacharya SK, Sarin MM and Somayajulu BLK(2003) Changes in surface productivity, sub-surface denitrification and SW monsoon during the Holocene: a multi proxy record from the eastern Arabian Sea. Holocene 13(5): 701-713.

Agnihotri R, Dutta K, Bhushan R and Somayajulu BLK (2002) Evidence of solar forcing of the Southwest Monsoon during the last Millennium. Earth and Planetary Science Letters 198: 521-527.

Agnihotri R, Siby K, Fernandes M, Reshma K, D'Souza W and Naqvi SWA (2008) Variability of subsurface denitrification and surface productivity in the coastal eastern Arabian Sea over the past seven centuries. Holocene 18(5): 755-764. 
Altabet MA, Murray DW and Prell WL (1999) Climatically linked oscillations in Arabian Sea denitrification over the past $1 \mathrm{~m} . \mathrm{y}$. : Implications for the marine $\mathrm{N}$ cycle. Paleoceanography 14(6): $732-743$.

Altabet MA, Francois R, Murray DW and Prell WL (1995) Climate-related variations in denitrification in the Arabian sea from 15N/14N ratios. Nature 373: 506-509.

Algeo TJ and Lyons TW (2006) Mo-total organic carbon co-variation in modern anoxic marine environments: implications for analysis of paleoredox and paleohydrographic conditions. Paleoceanography 21. PA1016, doi:10.1029/2004PA001112.

Banse K (1987) Seasonality of phytoplankton chlorophyll in the central and northern Arabian Sea. Deep-Sea Research 34: 713-723.

Bhushan R, Dutta K and Somayajulu BLK (2001) Concentrations and burial fluxes of organic and inorganic carbon on the eastern margins of the Arabian Sea. Marine Geology 178: 95-112.

Böning P, and Bard E (2009) Millennial/centennial-scale thermocline ventilation changes in the Indian Ocean as reflected by aragonite preservation and geochemical variations in Arabian Sea sediments Philipp. Geochimica et Cosmochimica Acta 73: 6771-6788 doi:10.1016/j.gca.2009.08.028.

Calvert SE, Pedersen TF, Naidu PD and Von Stackelberg U (1995) On the organic carbon maximum on the continental slope of the eastern Arabian Sea. Journal of Marine Research 53: 269-296.

Calvert SE, and Pedersen TF(1993) Geochemistry of Recent oxic and anoxic marine sediments: Implications for the geological record. Marine Geology 113: 67-88.

Deuser WG, Ross EH, Mlodzinska ZJ (1978) Evidence for rate of denitrification in the Arabian Sea. Deep-Sea Research 25: 431-445.

Dutta K, Bhushan R and Somayajulu BLK (2001) $\Delta \mathrm{R}$ correction values for the northern Indian Ocean. Radiocarbon, 43:483-488.

Ganeshram RS, Pedersen TF, Calvert SE, McNeill GW and Fontugne MR (2000) Glacial-interglacial variability in denitrification in the world's oceans: Causes and consequences. Paleoceanography 15: 361-376.

Ganeshram RS, Pedersen TF, Calvert SE and Murray JW (1995) Large changes in oceanic nutrient inventories from glacial to interglacial periods. Nature 376: 755-758.

Gupta AK, Mohan K, Sarkar S, Clemens SC, Ravindra R, and Uttam RK (2011) East-West similarities and differences in the surface and deep northern Arabian Sea records during the past 21 Kyr. Palaeogeography, Palaeoclimatology, Palaeoecology 301: $\quad 75-85$, DOI:10.1016/j.palaeo.2010.12.027.

Indermühle A, Stocker TF, Joos F, Fischer H, Smith HJ, Wahlen M, Deck B, Mastroianni D, Tschumi J, Blunier T, Meyer R, and Stauffer B (1999) Holocene carbon cycle dynamics based on $\mathrm{CO}_{2}$ trapped in ice at Taylor Dome, Antarctica. Nature 398: 121- 126.

Keeling RF, Koertzinger A, and Gruber N (2010) Ocean Deoxygenation in a warming world, Annual Review of Marine Science, 2:199-229, doi:10.1146/annurev.marine.010908.163855, 2010. 
Madhupratap SPK, Bhattathiri PMA, Kumar MD, Raghukumar S, Nair KKC, and Ramaiah N (1996) Mechanism of the biological response to winter cooling in the northern Arabian Sea. Nature 384: 549-552.

Menviel L, and Joos F (2012) Toward explaining the Holocene carbon dioxide and carbon isotope records: Results from transient ocean carbon cycle-climate simulations, Paleoceanography 27: PA1207, doi:10.1029/2011PA002224.

Meyers PA (1994) Preservation of elemental and source identification of sedimentary organic matter. Chemical Geology 114: 298-302.

Morse JW, Mucci A, and Millero FJ (1980) The solubility of calcite and aragonite in seawater at various salinities, temperatures and atmosphere total pressure. Geochimica et Cosmochimica Acta 44: 85-94.

Naqvi SWA (1991) Geographical extent of denitrification in the Arabian Sea in relation to some physical processes. Oceanologica Acta 14: 281-290.

Naik SS, Naidu PD, Govil P, and Godad S (2010) Relationship between Weights of Planktonic Foraminifer Shell and Surface Water $\mathrm{CO}_{3}{ }^{=}$Concentration during the Holocene and Last Glacial Period. Marine Geology 275 (1-4): 278-282, DOI:10.1016/j.margeo.2010.05.004.

Nair RR, Ittekkot V, Manganini S, Ramaswamy V, Haake B, Degens ET, Desai BN and Honjo S (1989) Increased particle fluxes to the oceans related to the monsoons. Nature 338: 749-751.

Paropkari AL, Babu CP and Mascarenhas A (1992) A critical evaluation of depositional parameters controlling the variability of organic carbon in Arabian Sea sediments. Marine Geology 107: 213-226.

Paulmier A, Ruiz-Pino D and Garcon $\mathrm{V}(2011) \mathrm{CO}_{2}$ maximum in the oxygen minimum zone (OMZ). Biogeosciences 8: 239-252.

Peeters FJC, Brummer G-J A and Ganssen G (2000) The effect of upwelling on the distribution and stable isotope composition of Globigerina bulloides and Globigerinoides ruber (planktic foraminifera) in modern surface waters of the NW Arabian Sea. Global and Planetary Change 34: 269-291.

Peters KE, Sweeney RE and Kaplan IR (1978) Correlation of carbon and nitrogen stable isotope ratios in sedimentary organic matter. Limnology and Oceanography23: 598-604.

Peterson LC andPrell WL (1985) Carbonate preservation and rates of climatic change: An 800-kyr record from the Indian Ocean. In:Sundquist ET and Broecker WS (eds) The Carbon Cycle and Atmospheric $\mathrm{CO}_{2}$ : Natural Variations Archean to Present, Geophysical Monograph Series, 32, pp. 251-269, AGU, Washington, D.C.

Pichevin L, Bard E, Martinez P, and Billy I (2007) Evidence of ventilation changes in the Arabian Sea during the late Quaternary: Implication for denitrification and nitrous oxide emission. Global Biogeochemical Cycles 21: GB4008, DOI:10.1029/2006GB002852.

Qasim SZ (1977) Biological productivity of the Indian Ocean. Indian Journal of Marine Sciences 6: $122-137$. 
Reichart GJ, Lourens LJ and Zachariasse WJ (1998) Temporal variability in the northern Arabian Sea Oxygen Minimum Zone (OMZ) during the last 225,000 years. Paleoceanography 13(6): 607-621.

Reichart GJ, Den Dulk M, Visser HJ, Vander Weijden CH and Zachariasse WJ (1997) A 225 kyr record of dust supply, paleoproductivity and the oxygen minimum zone from the Murray Ridge (Northern Arabian Sea). Palaeogeography Palaeoclimatology Palaeoecology 134: 149-169.

Reichart G-J, Brinkhuis H, Huiskamp F, and Zachariasse WJ (2004) Hyperstratification following glacial overturning events in the northern Arabian Sea. Paleoceanography 19: $\quad$ PA2013, DOI:10.1029/2003PA000900.

Resplandy L, LevyM, Bopp L, EchevinV, Pous S, Sarma VVSS and Kumar D (2012) Controlling factors of the oxygen balance in the Arabian Sea's OMZ. Biogeosciences 9: 5095-5109.

Sarmiento JL, Hughes TMC, Stouffer RJ, and Manabe S (1998) Simulated response of the ocean carbon cycle to anthropogenic climate warming. Nature 393: 245-249.

Schulte S, Rostek F, Bard E, Rullkotter J and Marchal O (1999) Variations of oxygen-minimum and primary productivity recorded in sediments of the Arabian Sea..Earth and Planetary Science Letters 173: 205-221.

Schulz H, von Rad U, and Erlenkeuser H (1998) Correlation between Arabian Sea and Greenland climate oscillations of the past 110,000 years. Nature 393: 54-57.

Singh AD (2007) Episodic preservation of pteropodes in the eastern Arabian sea: Monsoonal change, Oxygen minimum zone intensity and aragonite compensation depth. Indian journal of Marine Sciences 36: 4378-383.

Stramma L, Johnson GC, Sprintall J, and Mohrholz V (2008) Expanding Oxygen-Minimum Zones in the Tropical Oceans. Science 320: 655-658, DOI:10.1126/science.1153847.

Stuiver M, Reimer PJ, and Reimer RW (2005) CALIB 5.02 (program and documentation). http:/www.calib.qua.ac.uk/.

Von Rad U, Schaaf M, Michels KH, Schulz H and Sirocko F (1999a) A 5,000-year record of climate change in varved sediments from the Oxygen Minimum Zone off Pakistan (Northeastern Arabian Sea). Quaternary Research 51: 39-53.

von Rad U, Schulz H, Riech V, den Dulk M, Berner U, and Sirocko F (1999b) Multiple monsooncontrolled breakdown of oxygen-minimum conditions during the past $\quad 30,000 \quad$ years documented in laminated sediments off Pakistan. Palaeogeography, Palaeoclimatology, Palaeoecology 152: 129-161.

Von Stackelberg UV (1972) Faziesverteilung in Sedimentendes Indich-Pakistanischen KontinentalRandes (Arabisches Meer).Meteor Forschungsergebrisse, Reiche C(9) : 1-73.

Wyrtki K (1971) Oceanographic Atlas of the International Indian Ocean Expedition. National Science Foundation, Washington, DC, 531.

Zonneveld KAF, Versteegh GJM, Kasten S, .Eglinton TI, Emeis K-C, Huguet C, Koch BP, de Lange GJ, de Leeuw JW, Middelburg JJ, Mollenhauer G, Prahl FG, Rethemeyer J, and WakehamSG (2010) Selective preservation of organic matter in marine environments; processes and impact on the sedimentary record. Biogeosciences 7: 483-511. 


\section{Table captions:}

Table 1: Radiocarbon ages and calibrated ages for Core AAS9/19 from the eastern Arabian Sea.

\section{Figure captions:}

Fig. 1.Composite SeaWiFS chlorophyll-a concentrations $\left(\mathrm{mg} / \mathrm{m}^{3}\right)$ image (source: http://gdata1.sci.gsfc.nasa.gov/), for south-west monsoon (June-September; 2008) in the Arabian Sea. A distinct difference between the western and eastern Arabian Sea is noticed with the western side showing higher chlorophyll concentrations and hence more productive. Likewise the west coast of India shows higher chlorophyll concentrations. Thick circles indicate core locations of Core AAS9/19 (this study), 3268G5 and SK17.

Fig. 2.Downcore variations from the Core $\mathrm{AAS} 9 / 19$ in, a) $\mathrm{CaCO}_{3}, \%$ b) Organic Carbon $\%$, c) $\delta^{15} \mathrm{~N}$ (\%o), d) Nitrogen \%, e) $\mathrm{C} / \mathrm{N}$ ratios, f) $\delta^{13} \mathrm{C}_{\mathrm{org}}(\%)$, g) $\delta^{13} \mathrm{C}(\% \mathrm{o})$ of $\mathrm{G}$. ruber (values are in greyscale and the black line denotes 5 point adjacent averaging), h) $\mathrm{Ti}$ (ppm), i) $\mathrm{Cr} / \mathrm{Ti}, \mathrm{j}$ ) $\mathrm{Mo} / \mathrm{Ti}$ ratios, k) pteropod numbers, 1) aragonite content, and m) shell weights of G. ruber.

Fig. 3.Plot of ${ }^{13} \mathrm{C}(\%)$ versus $\mathrm{C} / \mathrm{N}$ ratios to ascertain provenance of organic matter.

Fig. 4a.SEM micrographs of G. ruber shells at a magnification of x 700 at 3.57 kyr interval Fig. 4b.SEM micrographs of $G$. ruber shells at a magnification of x 700 at 9.9 kyr interval. The entire foraminifera surface displays peeling and dissolution of spines (shown by arrows). 
Table 1:

\begin{tabular}{|l|l|l|l|}
\hline $\begin{array}{l}\text { Depth } \\
(\mathrm{cm})\end{array}$ & Measured age (years BP) & Error (years) & Calibrated age (years BP) \\
\hline 0 & 1680 & \pm 25 & 1115 \\
\hline 140 & 7340 & \pm 40 & 7678 \\
\hline 215 & 10795 & \pm 45 & 12035 \\
\hline 275 & 10960 & \pm 45 & 12335 \\
\hline
\end{tabular}




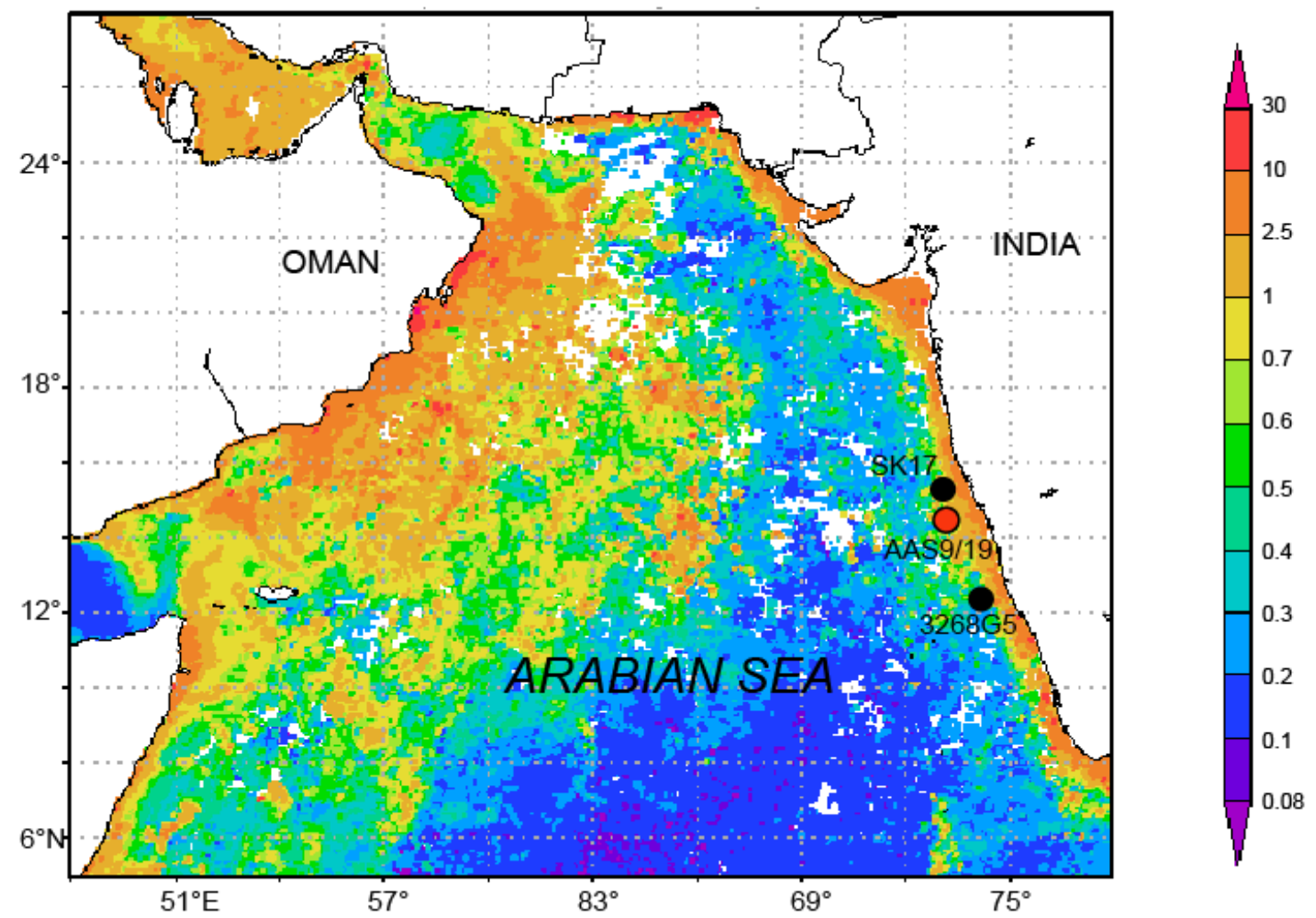

Fig. 1 


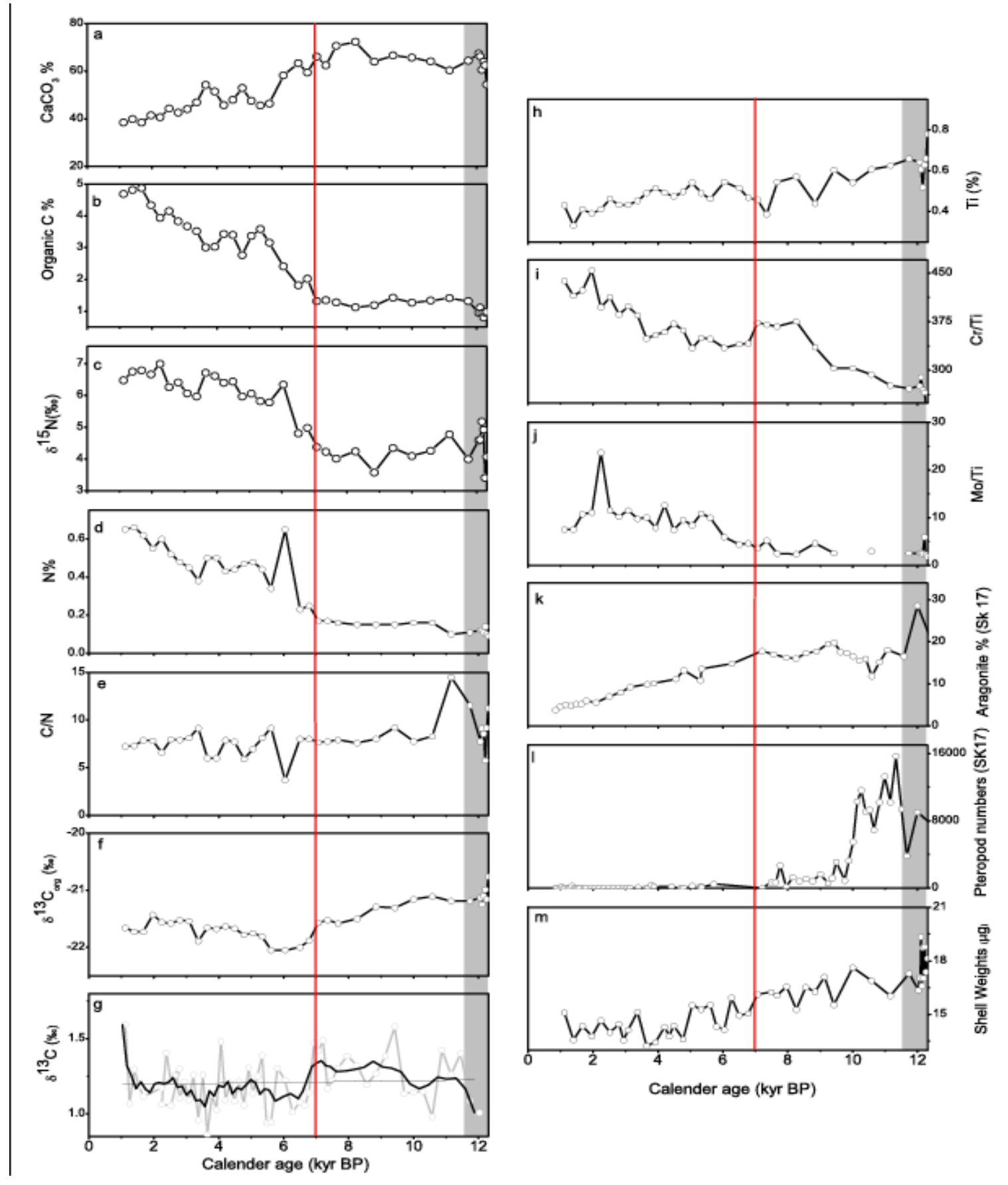

Fig. 2 


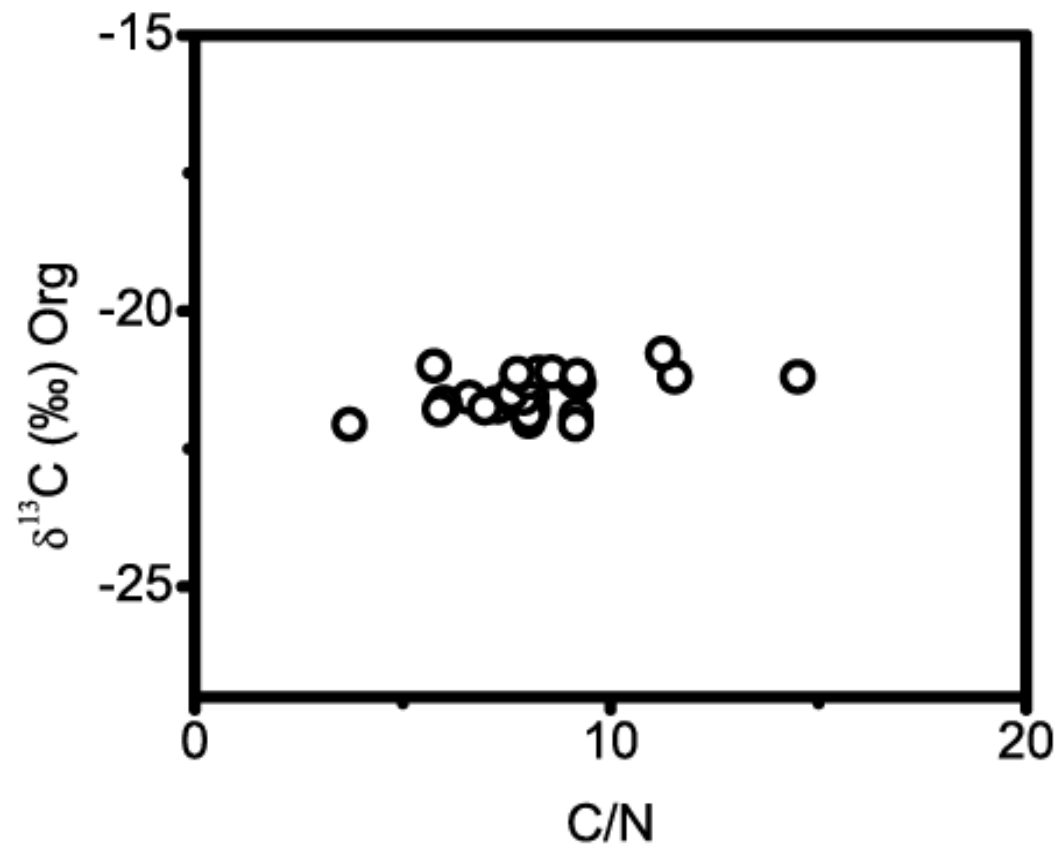

Fig. 3

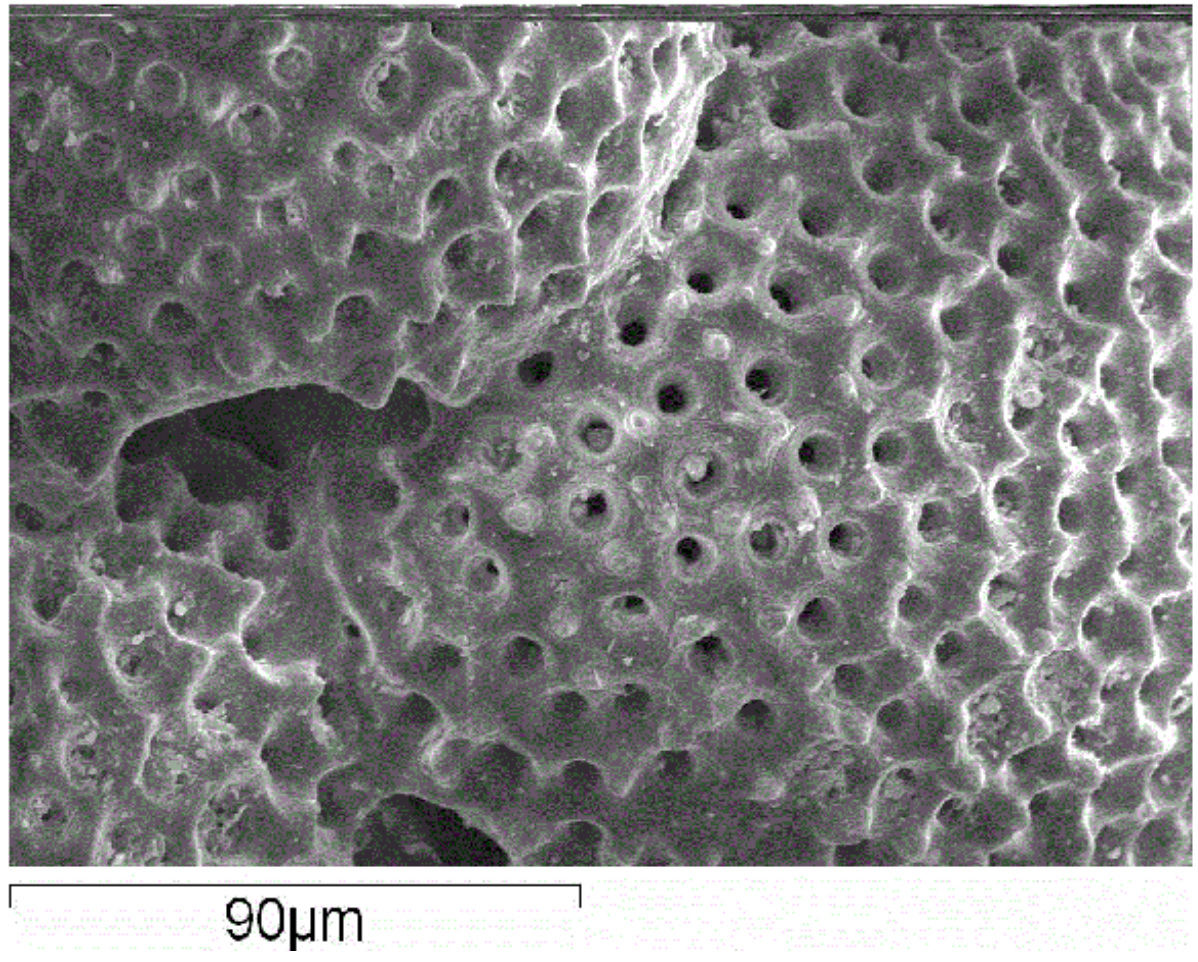

Fig. 4a 


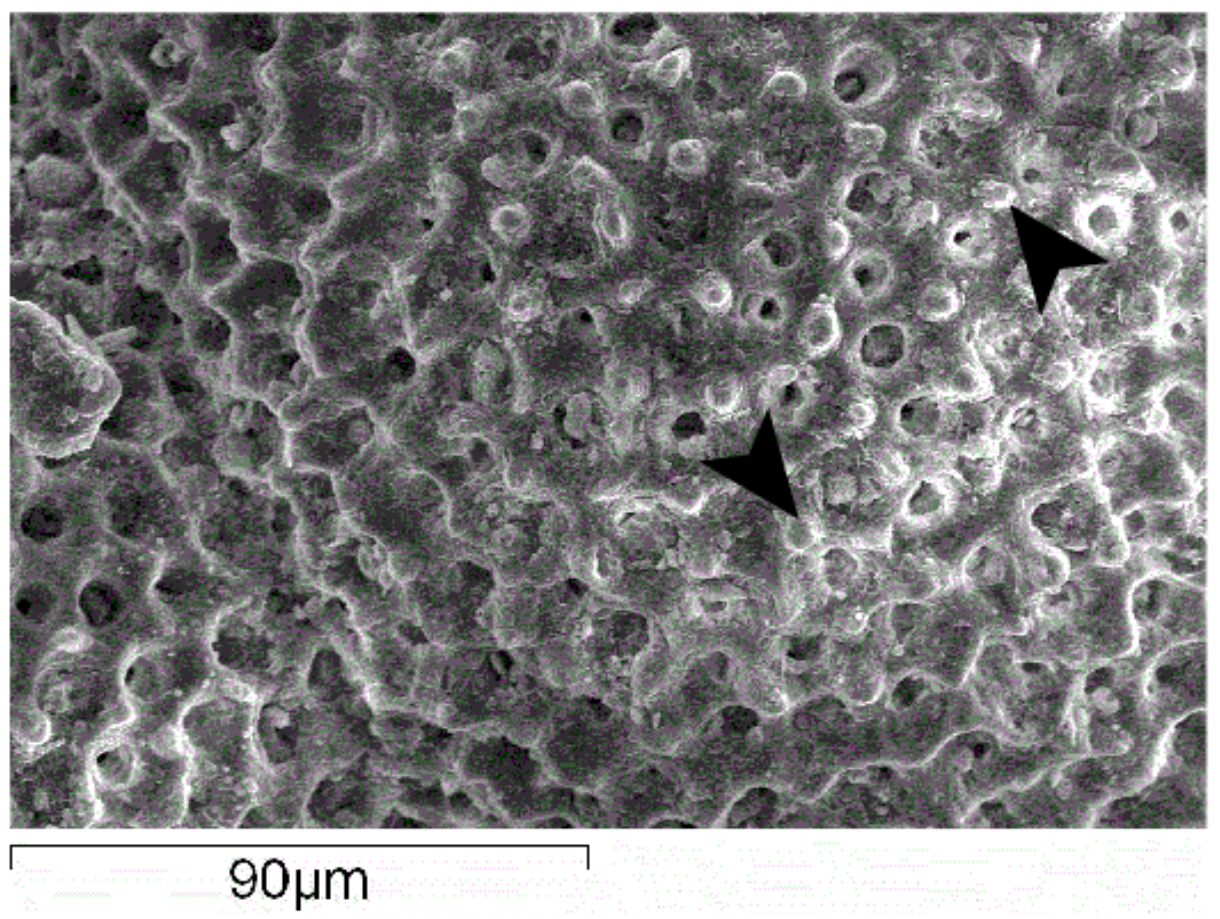

Fig. 4b 